\title{
Biochemical Properties of Bio-Fermented Strawberry Milk Beverage Supplemented with Probiotic Bacteria
}

\author{
Haron, E. M.M. ${ }^{(2)}$, Ayad, E.H.E. ${ }^{(1)}$, Bakrey, A.A. ${ }^{(2)}$ and Darwesh, S.M. ${ }^{(1)}$ \\ ${ }^{1}$ Food Sciences Department, Faculty of Agriculture Saba Basha, Alexandria University \\ ${ }^{2}$ Research Center, Department of Food Sciences, Dokki, Giza, Egypt
}

\begin{abstract}
Dairy products are an adequate alternative as functional foods since they present excellent nutritional value, have wide consumers acceptance, and have potential matrices for inoculation of probiotic microorganisms. Therefore this study aimed to produce a bio-fermented milk beverage fortified with different concentration strawberry juice 4,8 and $12 \%$. Using Abt5 probiotic culture composed of Lactobacillus acidophilus LA5, Bifidobacterium BB-12 and Streptococcus thermophilus. The chemical composition, physicochemical and biochemical properties of milk and juice were assessed. Fresh juice contained $91 \%$ moisture, $6.30 \%$ total sugar, $1.23 \%$ crude protein, $0.2 \%$ crude fat , $0.27 \%$ total ash, $\mathrm{pH} 3.3,0.81 \%$ total acidity, $7 \%$ total soluble solids (T.S.S), and phenolic compounds $667.22 \mathrm{mg}$ gallic acid equivalent in $100 \mathrm{~g}$ fruit juice (mg GAE/100g of juice), total anthocyanine 47.65 (mg cyaniding-3glycoside/L).Therefore, it shared a high antioxidant capacity inhibition ratio $(92 \%)$ through the evaluation of the free radical-scavenging effect on 1,1-diphenyl-2-picrylhydrazine (DPPH). Results indicated that the products incorporated with $4 \%$ followed by $8 \%$ juice were more accepted for 8 days at $4 \pm 2^{\circ} \mathrm{C}$. The recommended level of ABT5 as a probiotic culture was $10^{7} \mathrm{CFU} / \mathrm{ml}$ which were exceeded for various bio fermented milk treatments and remained above $10^{7} \mathrm{CFU} / \mathrm{ml}$ until the end of storage.
\end{abstract}

Keyword: Strawberry juice, Probiotic bacteria, Fermented milk, bioactive component, physicochemical characters, sensory evaluation.

\section{INTRODUCTION}

Nowadays, the largest segment of functional foods market worldwide is represented by milk and milk derived products fermented with probiotic microorganisms. Various health benefits of such foods include reduction in serum cholesterol, alleviation of lactose intolerance, reduction of diarrhea, prevention and suppression of colon cancer and stimulation of the immune system (Saarela et al., 2000). Recent studies indicated that continuous consumption of probiotic foods promotes a number of benefits including balance of intestinal flora as well as increased resistance against pathogenic (Zheng et al., 2014 and Zoumpopoulou et al., 2017). Dairy products are an adequate alternative as functional foods since they present excellent nutritional value, have wide consumers acceptance and are potential matrices for inoculation of probiotic microorganisms (Andrade et al., 2019 and Fernandes et al., 2018 ) Their components (ingredients) are sources of protein, minerals, and vitamins that provide favorable environment for the development of probiotics (He and Hekmat, 2015; Van Hooijdonk and Hettinga, 2015). Milk-based beverages, fermented milks are among the top, major probiotic foods consumed worldwide. However, food should contain an adequate concentration of probiotics; i.e., above $10^{6} \mathrm{UFC} / \mathrm{g}$ when consumed in order to have a beneficial effect on health (Lourens-Hattingh and Viljoen 2001). Combined products of fruits together with fermented milk product containing probiotic cultures has a unique possibility to produce a dairy product with all the benefits provided by this class of microorganisms, plus the pharmacological benefits 
provided by the fruit. Fruits are relatively low in energy and are an excellent source of antioxidants, prebiotic fibers and polyphenols, which can promote digestive health (Fernandez and Marette, 2017). Because of its highly nutritional and health benefit, fermented dairy products fortified with fruits received a lot of interest in recent decades. The use of different fruits has improved its nutritional and sensory properties (Çakmakçi et al., 2012). Fruit juices as well as dairy products offer several advantages for probiotic microorganisms (Pereira and Rodrigues, 2018). They are a rich source of nutrients (antioxidant, minerals, and vitamins) and their natural sugars contribute to the growth of probiotics.

Strawberries are a common and important fruit in the Mediterranean diet because of their high content of essential nutrients and beneficial phytochemicals, which seem to have relevant biological activity in human health. Among these phytochemicals, anthocyanin and ellagitannins are the major antioxidant compounds (Giampieri et al., 2012).

The objectives of this study were to evaluate the physicochemical and the sensory properties of the fermented milk beverage flavoured with strawberry juice and study the effects on the physicochemical properties and the viability of ABT5 culture during refrigerated storage.

\section{MATERIALS AND METHODS}

\section{Materials}

Approximately $5 \mathrm{~kg}$ of strawberries (Fragaria ananassa) were purchased from the local market in Alexandria city. Fresh full fat buffalo milk was purchased from the local market in Alexandria Governorate. Freeze dried culture (FD-DVS ABT-5-Prbiotic) composed of bacterial strains (Lactobacillus acidophilus LA-5, Bifidobacterium BB-12 and Streptococcs thermophilus) was obtained from Chr. Hansen's, Denmark.

\section{Technological methods \\ Preparation of strawberry juice}

The preparation of strawberry juice was carried out according to Galoburda et al., (2014). The strawberries were sorted, cleaned, washed, processed in (National, model SJ -390 blender, Egypt) until obtaining a homogenous mass, blend into polyethylene bags, then frozen and stored in frozen condition at $-23 \pm 2^{\circ} \mathrm{C}$ till used.

\section{Preparation of bio- fermented strawberry milk}

The frozen strawberry juice was thawed over night at $4 \pm 1^{\circ} \mathrm{C}$ in refrigerator. The thawed strawberry juice was added to the full fat milk at level of $4,8,12 \%(\mathrm{v} / \mathrm{v})$ concentration, The mixture was homogenized, heated at $85^{\circ} \mathrm{C}$ for 30 minutes, cooled at $40 \pm 2^{\circ} \mathrm{C}$, then inoculated with probiotic culture (FDDVS ABT-5-Prbiotic at $\mathbf{0 . 2} \mathbf{g} / \mathrm{l}$ ) concentration and incubated at $37 \pm 2^{\circ} \mathrm{C}$ to achieve $\mathrm{pH}$ value of around 4.6, from initial 6.5 and it lasted in average about 6 hours at $37^{\circ} \mathrm{C}$ before cooling at $4 \pm 2^{\circ} \mathrm{C}$ and stored at the same temperature in refrigerator for 8 days (Fig.1). 


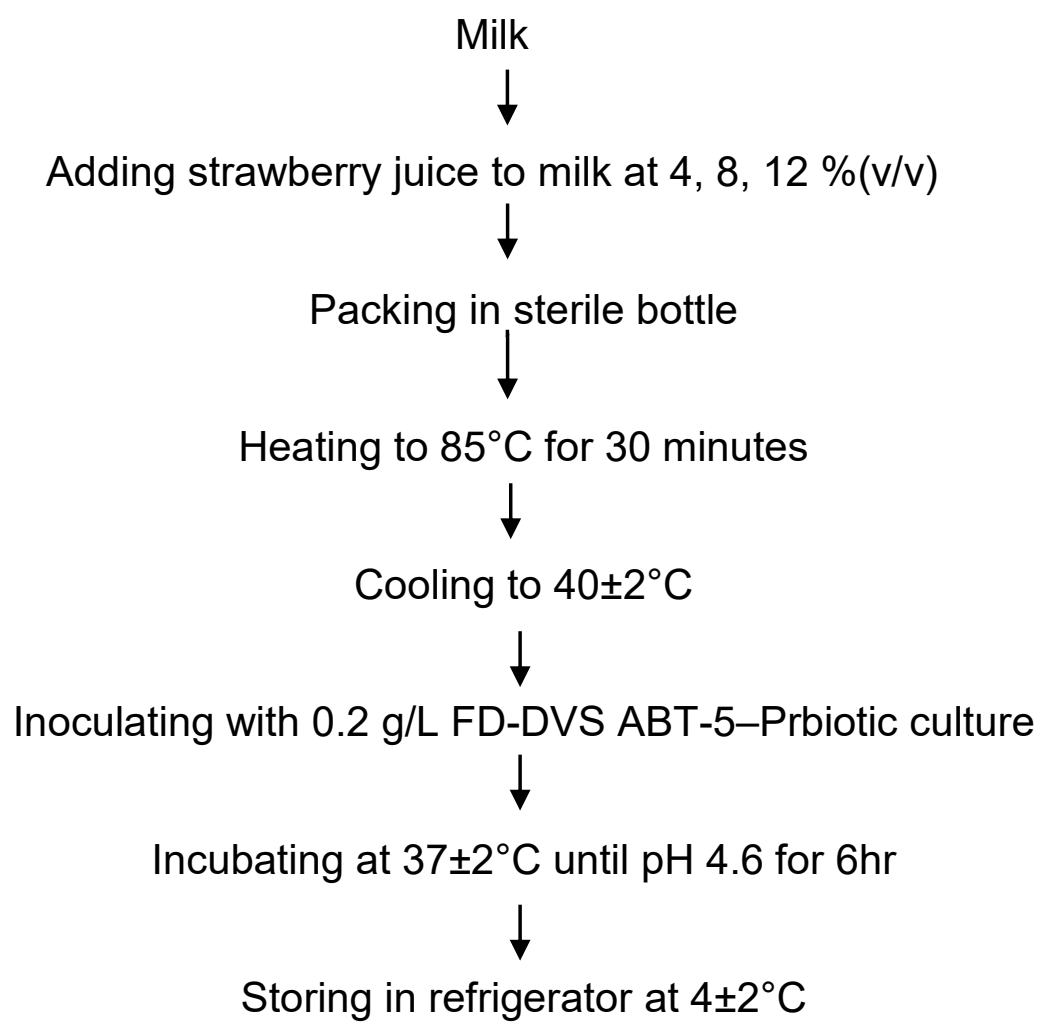

\section{Fig.(1). Flow chart for preparation of bio-fermented strawberry milk}

\section{Analytical methods}

\section{Physico-chemical analysis of milk}

The percent of fat, SNF, protein, lactose, density, freezing point (calculated), and ash of milk samples were determined by using Funke Gerber 3510 Laktostar milk content analyzer (Funke Gerber, Berlin, Germany) according to the manufacturer manual (Yıldız, 2008). Titritable acidity was determined as lactic acid \% according to AOAC (2008). pH value was measured using a $\mathrm{pH}$ meter (Jenway 3505, England) with a glass electrode standardized at $21.5^{\circ} \mathrm{C}$ over the range 6.7 according to AOAC (2008).

\section{Physico-chemical analysis of strawberry juice}

Analytical tests for strawberries juice were carried out in triplicates. Moisture, crude protein, crude fiber and ash contents were determine according to (AOAC 2008). Fat-soluble material was extracted from an oven-dried sample using mixtures of chloroform and methanol as described by Folch et al. (1957). Total soluble solid (T.S.S) were determined by hand refractometer (ATAGO Hand Refract meter, Brix ${ }^{\circ} 0-30 \%$, Japan). Titratable acidity (TA) as citric acid (\%) was determined by titration to $\mathrm{pH} 8.2$ with $0.1 \mathrm{M} \mathrm{NaOH}$ solution and expressed as $\mathrm{g}$ of citric acid per $100 \mathrm{ml}$ of juice. The $\mathrm{pH}$ measurements were performed using a digital pH meter (Jenway 3505, England). Total sugar (\%) was determined by phenol sulfuric acid method (Dubois et al., 1956).

Folin Ciocalteu reagent was used for analysis of total phenolics content of strawberry juice, using galic acid as standard for the calibration curve. The reaction mixture was kept in dark at ambient temperature $\left(22 \pm 2^{\circ} \mathrm{C}\right)$ for $2 \mathrm{hr}$ 
before measuring at wave length of $765 \mathrm{~nm}$ using UV-Visible spectrophotometer (APEI PD 303, Japan). The results were expressed as $\mathrm{mg}$ Gallic acid equivalent in $100 \mathrm{~g}$ of fruit juice (mg GAE/ $100 \mathrm{~g}$ of juice) (Maurya and singh., 2010).

Total anthocyanins (TA) content as $\mathrm{mg}$ as cyaniding-3-glucoside/L of puree. The TA was estimated by $\mathrm{pH}$ differential method using two buffer systems potassium chloride buffer $\mathrm{pH} 1.0(25 \mathrm{mM})$ and sodium acetate buffer $\mathrm{pH} 4.5(0.4 \mathrm{M})$ (Ozgen et al., 2008). The total flavonoid content was measured using catachin as standard for calibration curve according to Olajire and Azeez (2011).Total Antioxidant Capacity of strawberry juice several methods for determination of antioxidant capacity were used: FRAP, DPPH. The FRAP (ferric reducing/antioxidant power) assay was carried out according to Quisumbing (1978).

The antioxidant capacity of strawberry juice was studied through the evaluation of the free radical-scavenging effect on the 1,1-diphenyl-2picrylhydrazine (DPPH) radical. The determination was based on the method proposed by Marxen et al. (2007).

\section{Microbiological analysis}

The convention diluting pouring plate technique was followed for enumerating total microbes in the samples using PCA (Oxoid, England). All plates were counted and the two replicates from the same dilution were calculated directly by colony forming unit (CFU g ${ }^{-1}$ or $\mathrm{ml}^{-1}$ ).

For counting Lactic acid bacteria group, the MRS agar (Biolife) was used as recommended by the standard methods for examination of dairy products. The plates were incubated for $48 \mathrm{~h}$ at $37^{\circ} \mathrm{C}$ (DeMan et al., 1960).

Enumeration of yeast and molds was made as recommended by the standard method for examination of dairy product (Marshall, 1993), using the Rose Bengal media. The plates were incubated for 5 day at $21^{\circ} \mathrm{C}$. Violet red bile agar (VRBA) was used for enumerating coliform bacteria as described by (Marshall, 1993). The plates were incubated at $37^{\circ} \mathrm{C}$ for 48 hours.

\section{Sensory evaluation}

Ten experienced panelists were chosen for the assessment of the sensory attributes of bio fermented beverage samples. Taste, Color, Appearance, and overall grade of the samples were evaluated. The introduced sensory attributes allowed the differentiation of samples. Samples were coded and were kept at $25^{\circ} \mathrm{C}$ for $1 \mathrm{~h}$ after the manufacturing process before sensory assessment. Samples were served in $125 \mathrm{ml}$ plastic cups. All sensory attributes were assessed by the panelists and were rated using a 4-point scale as 1=Bad, 2= Sufficient, 3= Good and 4= Very good according to Poste (1991).

\section{Statistical analysis}

The effect of strawberry juice addition on each parameter was estimated by ANOVA ( $P<0.05)$ using minitab ${ }^{\circledR}$ statistical software (Çelik et al., 2009). Statistically different groups were determined by Duncan's multiple range tests. 


\section{RESULT AND DISCUSSION}

\section{Physico- chemical analysis of strawberry juice}

The results of proximate composition analysis of fresh strawberry juice are shown in Table (1). As shown in the Table, the fresh strawberry juice contained $91 \%$ moisture, $0.2 \%$ crude fat, $1.23 \%$ crude protein, $1 \%$ crude fiber, $0.27 \%$ ash, respectively. These results are in accordance with these of Sabina et al., (2011) and Hossain et al., (2016).

Table (1). Proximate composition of strawberry juice (fresh weight)

\begin{tabular}{lc}
\hline \multicolumn{1}{c}{ Proximate composition } & $\begin{array}{c}\text { Strawberry juice } \\
(\%)\end{array}$ \\
\hline Moisture & $91.00 \pm 0.03$ \\
Crude fat & $0.20 \pm 0.10$ \\
Crude protein & $1.23 \pm 0.15$ \\
Crude fiber & $1.00 \pm 0.01$ \\
Ash & $0.27 \pm 0.06$ \\
\hline \multicolumn{1}{c}{${ }^{*}$ Mean $\pm S D$} &
\end{tabular}

The results of physicochemical properties of fresh Strawberry juice was as follow: total soluble solids content (T.S.S) $7^{\circ}$ Brix, total sugar $6.30 \%$ (Keutgen et al., 2007), Titritable acidity (as citric acid) $0.81 \%, \mathrm{pH}$ value 3.3 and viscosity 924.7 mpas. The $\mathrm{pH}$ and the titrable acidity of Strawberry juice were in agreement with Galoburda et al. (2014), Mansour et al.(2014), Alcaraz-Mármol et al. (2017).

Table (2). Physicochemical characteristic of strawberry juice (freshweight)

\begin{tabular}{lc}
\hline \multicolumn{1}{c}{ Physicochemical characteristic } & Strawberry juice* $^{*}$ \\
\hline Total soluble solid (Brix) & \\
Total sugar (\%) & $7.00 \pm 0.58$ \\
Titratable acidity as citric acid (\%) & $6.30 \pm 0.58$ \\
pH value & $0.81 \pm 0.02$ \\
Viscosity (mPas) ${ }^{\star *}$ & $3.30 \pm 0.00$ \\
\hline${ }^{*}$ Mean $\pm S D$ & $924.76 \pm 4.51$ \\
\hline
\end{tabular}

Phenolic compounds in fruits and vegetables have important contributions to sensory attributes, as well as potential health benefits (Radunic et al., 2015). Total phenolic, total flavonoid and total anthocyanin content in strawberry juice was shown in Table (3).

Total phenolic content were $667.28 \pm 10.18 \mathrm{GAE} / 100 \mathrm{~g}$. These result in an agreement with that obtained by Mahmood et al., (2012) and higher than that obtained by Treftz and Omaye (2015). Flavanoid content was $367.3 \pm 2.28 \mathrm{mg}$ catchin/100g, it is lower than that found by De Souza et al., (2014). 
Total anthocyanin content in the Strawberry juices was $47.61 \mathrm{mg}$ (cyaniding-3-glycoside/L) which was in agreement with that reported by Kelebek and Selli (2011) and was lower than found by de Jesús Ornelas-Paz et al.(2013).

Table (3). Total phenolics, flavonoids and anthocyanin content of the Strawberry juice

\begin{tabular}{lc}
\hline \multicolumn{1}{c}{ Component (fresh weight) } & Strawberry juice $^{*}$ \\
\hline Total phenolic mg GAE/100g & $667.28 \pm 10.18$ \\
Total flavonoids mg catchin/100g & $367.33 \pm 22.81$ \\
Total anthocyanin (mg cyaniding-3-glycoside/L ) & $47.61 \pm 2.65$ \\
\hline
\end{tabular}

*Mean \pm SD

mg GAE/100g: gallic acid equivalent in $100 \mathrm{~g}$ of fruit juice

Previous studies stated that strawberry fruit is rich in anthocyanin and it has many health benefits' such as antioxidant ability, anti-inflammatory, anticancer and other physiological functions (Giampieri et al., 2012).

Antioxidant potentials of strawberry juices to scaving DPPH was 92 $\pm 0.01 \%$ which indicated the high antioxidant capacity in strawberry juice. These results are in agreement with that reported by Bursać et al., (2009). The reducing power method was used to confirm the results from the DPPH test, the mean values was $91.1 \pm 3.19 \mu \mathrm{g}$ ascorbic acid $/ \mathrm{g}$.

The higher reducing power indicated presence of reductions which are able to break free radical chains by donating hydrogen atoms and thus converting them to a more stable non-reactive species (Huang et al, 2005) and Zhang et al. (2010).

Table (4). Antioxidant activity of the Strawberry juices

\begin{tabular}{|c|c|}
\hline Antioxidant activity & Strawberry juice* \\
\hline Antioxidant capacity DPPH mg/l & $92 \pm 0.01$ \\
\hline $\begin{array}{l}\text { Reducing power } \\
\mu g \text { ascorbic acid/g extract }\end{array}$ & $91.1 \pm 3.1$ \\
\hline
\end{tabular}

\section{Some physicochemical properties of bio-fermented milk beverage:}

$\mathrm{pH}$ :

Fermented milk beverage $\mathrm{pH}$ values without and with Strawberry juice are shown in Figure (2) .The $\mathrm{pH}$ is inversely proportional to the acidity of any medium. It is revealed that the $\mathrm{pH}$ of fermented milk beverage (control) was found to 4.6. $\mathrm{pH}$ values decreased gradually with addition of 4,8 and $12 \%$ strawberry juice. This could be attributed to the low $\mathrm{pH}$ of Strawberry juice (3.30). Strawberry juice positively affected the rate of acid production. As the $\mathrm{pH}$ decreased, acidity increased. This may be due to fermentation of lactose, 
which produce lactic and acetic acid during fermentation and storage period. These results are in agreement with Hamad et al. (2013).

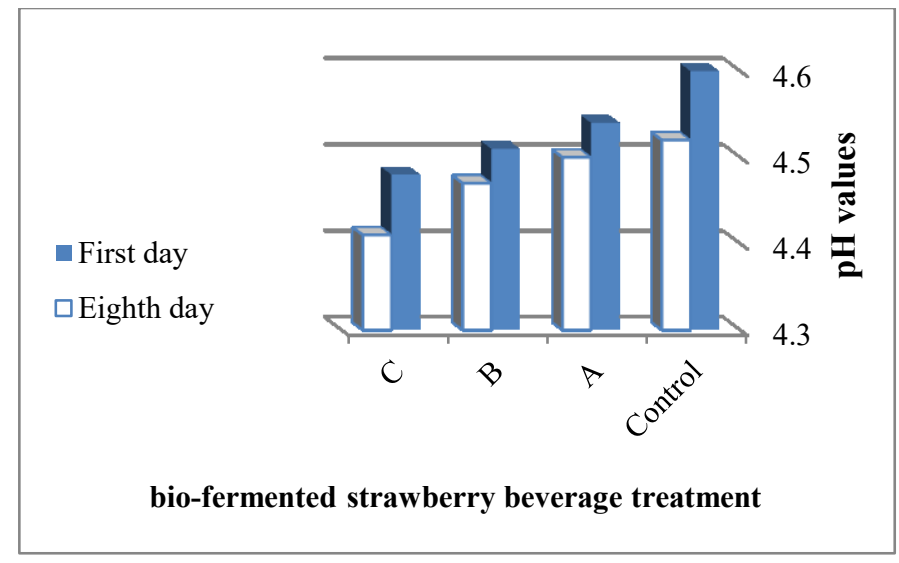

Fig. (2). changes of pH during storage period

Control without juice, A, B, C are fermented milk beverage treatments made milk adding 4,8 and $12 \%$ strawberry juice, respectively.

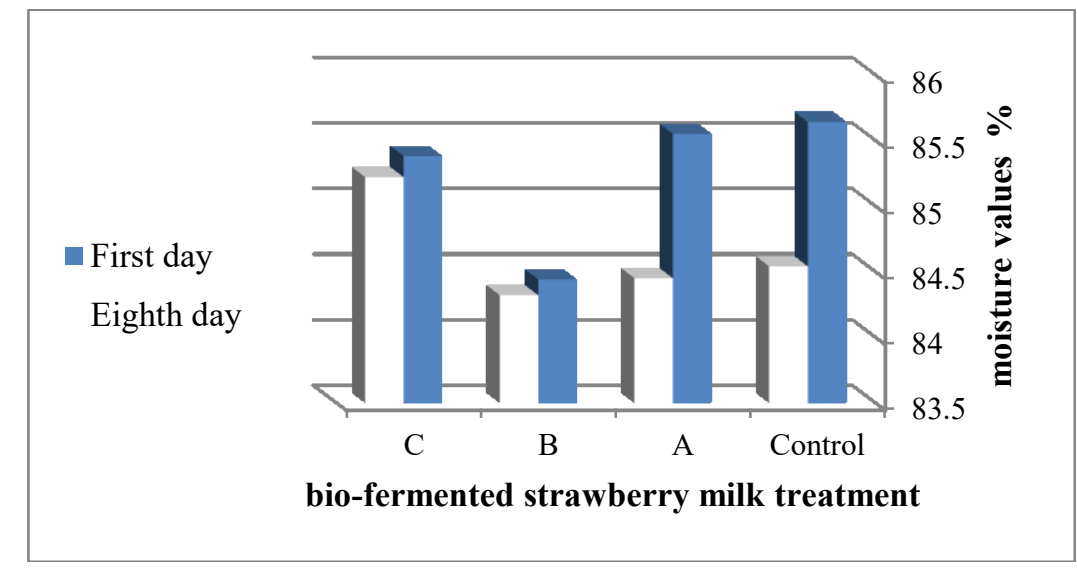

Fig. (3). Change of moisture during storage period

Control without juice, A, B, C are fermented milk beverage treatments made milk adding 4,8 and $12 \%$ strawberry juice, respectively.

\section{Moisture content:}

Moisture content of fermented milk beverage without Strawberry juice (control) was recorded as the highest (85.64 \%) among all samples, Figure (3). The addition of strawberry juice increased the TS of fermented milk beverage and therefore decreases in the moisture content of product. The moisture contents of fermented milk beverage with strawberry juice were $85.55,84.44$ and $85.38 \%$ at 4,8 and $12 \%$ concentrations, respectively while decrease at eighth day to $84.45,84.32$ and $85.22 \%$, respectively. Moisture content and the total solids affected the texture, low moisture content and high total solid 
increased the firmness and consistency of yogurt and therefore affected on mouth feeling (Yousef et al., 2013).

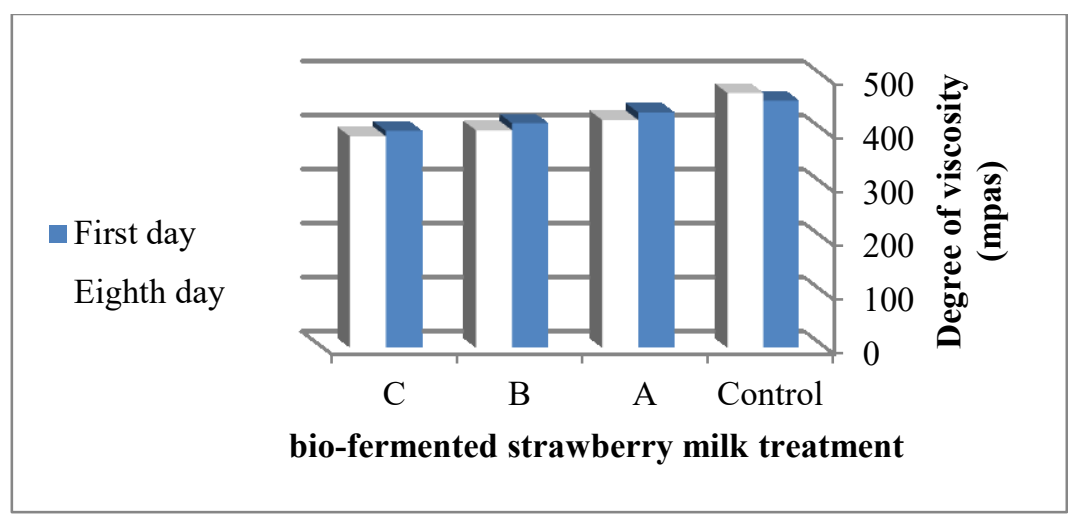

Fig. (4). Change of viscosity (mPas) during storage period

Control without juice, A, B, C are fermented milk beverage treatments made milk adding 4,8 and $12 \%$ strawberry juice, respectively.

\section{Viscosity:}

The viscosity is an important characteristic of foods due to its relation to the density of product. The viscosity was changed in the fermented milk beverage with added Strawberry juice (4, 8 and 12\%) as presented in Figure (4). The viscosity of fermented milk beverage without Strawberry juice (control) (471 mPas) was higher than that of fermented milk beverage based on strawberry juice being 435,415 and $401 \mathrm{mPas}$ at concentrations 4,8 and $12 \%$, respectively. It was evident that increasing the strawberry juice concentration reduced significantly the viscosity value of the fermented milk beverage.

The viscosity of bio fermented milk without or with Strawberry juice increased continuously up to 8 days of storage. It was noted that the lower the $\mathrm{pH}$ of the fermented milk beverage, the more resistant the gel network was to syneresis. The increase in acidity during the fermentation and storage period increases the stability of the fermented milk beverage (Longton, 1991). The addition of higher concentration of concentrated fruit juices decreases the water-holding capacity of protein (i.e. diluting the protein content in the milk base); thus the viscosity of the yoghurt decreases. (Ramaswamy and Basak 1992; Akyüz and Coflkun ,1995). It has been reported that the addition of fruit juices or pulps might be deleterious to the survivability of some species and strains of probiotic microorganisms in food products, particularly due to acidity and the presence of antimicrobial compounds. Buriti et al., (2007) and do Espírito Santo et al., (2012) stated that with increasing of guava pulp amounts added to goat's milk, total solids (TS) content raised but fat and total protein concentrations slightly lowered. The $\mathrm{pH}$ values gradually decreased with increasing strawberry juice concentrations. 


\section{Probiotic enumeration:}

The probiotic enumerations of the samples after preparation of the beverages (on the first day and $8^{\text {th }}$ day of refrigerated storage are shown in Table (5). The addition of fruit juices or pulps might be deleterious to the survivability of some species and strains of probiotic microorganisms in food products, particularly due to acidity and the presence of antimicrobial compounds do Espírito Santo et al. (2012). In the present study, it was verified that ABT5 culture is good viability in the presence of strawberry juice. Treatments $B(8 \%)$ contained strawberry juice had the highest numbers level of ABT5 culture $\left(4.8 \times 10^{9}\right)$ at the end of storage at $4 \pm 2^{\circ} \mathrm{C}$. This may be attributed to high acid production and accumulation in fermented milk with strawberry juice during storage $4 \pm 2^{\circ} \mathrm{C}$ and nutrients in bio- fermented strawberry milk.

Table (5). Microbiology analysis of bio-fermented strawberry milk starter (ABT5) during refrigerated storage at $4 \pm 2^{\circ} \mathrm{C}$

\begin{tabular}{cccccc}
\hline Treatment & $\begin{array}{c}\text { Storage } \\
\text { period } \\
\text { (days) }\end{array}$ & $\begin{array}{c}\text { Total } \\
\text { Count } \\
\text { CFU/ml }\end{array}$ & $\begin{array}{c}\text { LAB } \\
\text { CFU/ml }\end{array}$ & $\begin{array}{c}\text { Coliform } \\
\text { CFU/ml }\end{array}$ & $\begin{array}{c}\text { Yeasts and } \\
\text { Mould } \\
\text { CFU/ml }\end{array}$ \\
\hline Control & Fresh & $3.3 \times 10^{7}$ & $5.2 \times 10^{7}$ & ND & ND \\
& $\mathbf{1}$ & $3.2 \times 10^{7}$ & $3.0 \times 10^{8}$ & ND & ND \\
& $\mathbf{4}$ & $4.5 \times 10^{7}$ & $8.1 \times 10^{8}$ & ND & ND \\
& $\mathbf{8}$ & $5.0 \times 10^{7}$ & $9.0 \times 10^{8}$ & ND & ND \\
\hline A & Fresh & $3.0 \times 10^{7}$ & $5.6 \times 10^{7}$ & ND & ND \\
\hline & $\mathbf{1}$ & $3.0 \times 10^{7}$ & $2.0 \times 10^{7}$ & ND & ND \\
& $\mathbf{4}$ & $3.8 \times 10^{7}$ & $6.5 \times 10^{8}$ & ND & ND \\
\hline B & $\mathbf{8}$ & $4.0 \times 10^{7}$ & $8.5 \times 10^{8}$ & ND & ND \\
\hline & Fresh & $4.0 \times 10^{7}$ & $6.7 \times 10^{7}$ & ND & ND \\
\hline $\mathbf{C}$ & $\mathbf{1}$ & $1.6 \times 10^{7}$ & $1.3 \times 10^{8}$ & ND & ND \\
& $\mathbf{4}$ & $2.4 \times 10^{8}$ & $4.1 \times 10^{9}$ & ND & ND \\
& $\mathbf{8}$ & $3.0 \times 10^{8}$ & $\mathbf{4 . 8 \times 1 0 ^ { 9 }}$ & ND & ND \\
\hline & Fresh & $3.0 \times 10^{7}$ & $4.0 \times 10^{7}$ & ND & ND \\
& $\mathbf{1}$ & $3.8 \times 10^{7}$ & $3.0 \times 10^{8}$ & ND & ND \\
& $\mathbf{4}$ & $2.1 \times 10^{7}$ & $4.7 \times 10^{8}$ & ND & ND \\
\hline
\end{tabular}

Control without juice, A, B, C are fermented milk beverage treatments made milk adding 4,8 and $12 \%$ strawberry juice, respectively.

Fresh: analyses were conducted after fermentation (6 hrs).

ND: Not detected

These result showed that coliform, moulds and yeast did not detected in all treatments it was observed that the total Lactic Acid Bacteria (LAB) count increased during the storage period for all treatment. The highest $L A B$ count $4.8 \times 10^{9} \mathrm{CFU} / \mathrm{ml}$ was found in treatment number (B) flowed by $(\mathrm{C})$ $1.1 \times 10^{9} \mathrm{CFU} / \mathrm{ml}$, while the control treatment was the least being $5.2 \times 10^{7}$ $\mathrm{CFU} / \mathrm{ml}$. These results in agreement with those of (Jayamanne and Adams, 2006), who reported that to be considered a probiotic, the product should present a concentration of probiotic microorganisms above $10^{6} \mathrm{CFU} / \mathrm{ml}$. 
Table (6). Sensory properties of bio-fermented strawberry milk during storage

\begin{tabular}{ccccc}
\hline Treatments & Fresh $^{*}$ & $\mathbf{1}$ & $\mathbf{4}$ & $\mathbf{8}$ \\
\hline \multicolumn{5}{c}{ Days } \\
\hline Control & $8.25 \pm 0.89$ & $8.25 \pm 0.89$ & $8.66 \pm 0.53$ & $8.00 \pm 0.53$ \\
A & $8.00 \pm 0.52$ & $8.00 \pm 0.52$ & $8.25 \pm 0.71$ & $8.10 \pm 0.00$ \\
B & $8.36 \pm 0.71$ & $8.36 \pm 0.71$ & $8.50 \pm 0.53$ & $8.60 \pm 0.52$ \\
C & $7.00 \pm 0.52$ & $7.00 \pm 0.25$ & $7.00 \pm 0.46$ & $7.00 \pm 0.00$ \\
\hline \multicolumn{5}{c}{ Viscosity } \\
\hline Control & $8.50 \pm 0.52$ & $8.50 \pm 0.52$ & $8.50 \pm 0.53$ & $8.20 \pm 0.76$ \\
A & $8.37 \pm 0.52$ & $8.37 \pm 0.52$ & $8.25 \pm 0.74$ & $8.12 \pm 0.35$ \\
B & $7.62 \pm 0.53$ & $7.62 \pm 0.53$ & $7.30 \pm 0.52$ & $7.25 \pm 0.46$ \\
C & $7.12 \pm 0.35$ & $7.12 \pm 0.35$ & $7.12 \pm 0.35$ & $7.00 \pm 0.35$ \\
\hline \multicolumn{5}{c}{ Colour } \\
Control & $8.12 \pm 0.00$ & $8.12 \pm 0.00$ & $8.12 \pm 0.83$ & $8.12 \pm 0.76$ \\
A & $7.50 \pm 0.53$ & $7.50 \pm 0.53$ & $7.50 \pm 0.64$ & $7.52 \pm 0.52$ \\
B & $8.25 \pm 0.35$ & $8.25 \pm 0.35$ & $8.22 \pm 0.76$ & $8.25 \pm 0.46$ \\
C & $9.00 \pm 0.71$ & $9.00 \pm 0.71$ & $9.00 \pm 0.76$ & $9.00 \pm 0.35$ \\
\hline \multicolumn{5}{c}{ Over accept } \\
Control & $8.22 \pm 0.52$ & $8.22 \pm 0.52$ & $8.30 \pm 0.52$ & $8.12 \pm 0.35$ \\
A & $8.12 \pm 0.52$ & $8.12 \pm 0.52$ & $8.35 \pm 0.46$ & $8.20 \pm 0.00$ \\
B & $8.35 \pm 0.46$ & $8.35 \pm 0.46$ & $8.87 \pm 0.35$ & $8.82 \pm 0.00$ \\
C & $8.25 \pm 0.71$ & $8.25 \pm 0.71$ & $8.27 \pm 0.52$ & $8.00 \pm 0.35$ \\
\hline
\end{tabular}

Control without juice. $\mathrm{A}, \mathrm{B}, \mathrm{C}$ are fermented milk beverage treatments made milk adding 4,8 and $12 \%$ strawberry juice, respectively .

Table (6) illustrated that the sensory properties of bio- fermented strawberry milk control and varying levels of strawberry juice during storage period. The data showed that, the sensory properties such as flavor, taste, viscosity, color, appearance and over acceptability.

\section{Flavor and taste:}

From Table (6) the $8 \%$ fermented beverage milk had the highest flavor score compared to other samples (Abdalla et al., 2015).

\section{Viscosity:}

Viscosity of bio-fermented strawberry milk were affected by the addition of juice and throughout the storage period. The score of beverage (T0\%) control was higher in viscosity compared to samples (Güven and Karaca ,2002).

\section{Color and appearance:}

The resulted scores of the products color revealed that increasing the concentration of strawberry juice enhanced the color and the appearance of the bio- fermented strawberry juice treatments, particularly $12 \%$, and during the storage. These results were in agreement with (Kavas and Kavas, 2016), who 
reported that increasing the guava pulp concentration to $15 \%$ improved the products color.

\section{Over all acceptability:}

As shown in Table (6) overall score of bio-fermented strawberry juice were significantly affected by the addition of juice and throughout the storage period. Treatment B geared was received the highest score among fermented strawberry milk. (Abdalla et al., 2015).

\section{CONCLUSION}

It can be noted that milk fermented with strawberry juice and probiotic bacteria (ABT5) could be manufactured as an alternative probiotic dairy product and can be recommended for consumption. The results showed that the bio fermented strawberry milk beverage contained LAB could serve as a healthy beverage for consumers.

\section{REFERENCES}

Abdalla, M. O., Fawi, N. M., Ahmed, M. S., Mohamed, G. E., and Ahmed, G. E. (2015). Quality Evaluation of Stirred Yoghurt Flavoured with Guddaim (Grewia tenax) Fruit. Asian Journal of Agriculture and Food Sciences (ISSN: 2321-1571): 3(01).

Akyuz, N. and Coskun, H. (1995). Production of Fruit Yogurt In Yogurt pp 285294. National Productivity Center No548. Ankara: Mert Press.

Alcaraz-Mármol, F., Nuncio-Jáuregui, N., García-Sánchez, F., MartínezNicolás, J. J., and Hernández, F. (2017). Characterization of twenty pomegranate (Punica granatum L.) cultivars grown in Spain: Aptitudes for fresh consumption and processing. Scientia horticulturae, 219: 152160.

Andrade, M. R. D., Martins, T. R., Rosenthal, A., Hauck, J. T., and Deliza, R. (2019). Fermented milk beverage: formulation and process. Ciência Rural, 49(3).

Associtaion of Official Analytical Chemists (200^). AOAC international (18 end). Gaitherburg: Maryland, USA.

Bursać Kovačević, D., Levaj, B., and Dagović-Uzelac, V. (2009). Free radical scavenging activity and phenolic content in strawberry fruit and jam. Agriculturae Conspectus Scientificus, 74: 155-159.

Buriti, F. C., Komatsu, T. R., and Saad, S. M. (2007). Activity of passion fruit (Passiflora edulis) and guava (Psidium guajava) pulps on Lactobacillus acidophilus in refrigerated mousses. Brazilian Journal of Microbiology, 38: 315-317.

Çakmakçi, S., Çetin, B., Turgut, T., Gürses, M., and Erdoğan, A. (2012). Probiotic properties, sensory qualities, and storage stability of probiotic banana yogurts. Turkish Journal of Veterinary and Animal Sciences, 36: 231-237.

Çelik, Ş., Durmaz, H., Şat, İ. G., and Şenocak, G. (2009). Andız pekmezi içeren set tipi yoğurtların bazı fizikokimyasal ve mikrobiyolojik özellikleri. GIDA, 34: 213-218. 
De Man, J. C., Rogosa, D., and Sharpe, M. E. (1960). A medium for the cultivation of lactobacilli. Journal of applied Bacteriology, 23(1):130-135.

De Souza, V. R., Pereira, P. A. P., Da Silva, T. L. T., de Oliveira Lima, L. C., Pio, R., and Queiroz, F. (2014). Determination of the bioactive compounds, antioxidant activity and chemical composition of Brazilian blackberry, red raspberry, strawberry, blueberry and sweet cherry fruits. Food Chemistry, 156: 362-368.

de Jesús Ornelas-Paz, J., Yahia, E. M., Ramírez-Bustamante, N., PérezMartínez, J. D., del Pilar Escalante-Minakata, M., Ibarra-Junquera, V., and Ochoa-Reyes, E. (2013). Physical attributes and chemical composition of organi strawberry fruit (Fragaria $x$ ananassa Duch, Cv. Albion) at six stages of ripening. Food Chemistry, 138: 372-381.

do Espírito Santo, A. P., Cartolano, N. S., Silva, T. F., Soares, F. A., Gioielli, L. A., Perego, P., and Oliveira, M. N. (2012). Fibers from fruit byproducts enhance probiotic viability and fatty acid profile and increase CLA content in yoghurts. International Journal of Food Microbiology, 154: 135-144.

Dubois, M., Gilles, K., Hamilton, J., Rebers, P. and Smith, F. (1956). Colorimetric method for determination of sugars and related substances. Analytical Chemistry, 28:350-356.

Fernandez, M. A., and Marette, A. (2017). Potential health benefits of combining yogurt and fruits based on their probiotic and prebiotic properties. Advances in Nutrition, 8: 155S-164S.

Fernandes Pereira, A. L.; S. Rodrigues. Turning Fruit Juice Into Probiotic Beverages A2 - Rajauria, Gaurav. In: B. K. Tiwari (Ed.). Fruit Juices. San Diego: Academic Press (2018).Turning Fruit Juice In to Probiotic Beverages A2 - Rajauria, Gaurav, p.279-287.

Folch, J., Lees, M. and Sloane Stanley, G. H. (1957). A simple method for the isolation and purification of total lipides from animal tissues. J. Biol Chem., 226: 497-509.

Galoburda,R., Boca, S., Skrupskis, I. and Seglina, D. (2014). Physical and chemical parameters of strawberry puree. In $9^{\text {th }}$ Baltic Conference on Food Science and Technology "Food for Consumer Well-Being" (p. 172).

Giampieri, F., Tulipani, S., Alvarez-Suarez, J. M., Quiles, J. L., Mezzetti, B., andBattino, M. (2012). The strawberry: composition, nutritional quality, and impact on human health. Nutrition, 28:9-19.

Güven, M., and Karaca, O. B. (2002). The effects of varying sugar content and fruit concentration on the physical properties of vanilla and fruit ice-cream-type frozen yogurts. International Journal of Dairy Technology, 55: 27-31.

Hamad, H. E., Sulieman, A. M. E., and Salih, Z. A. (2013). Quality aspects of the sudanese fermented milk (Robe) supplemented with gum arabic powder. Discourse Journal of Agricultural Food Science;1: 8-13.

He, S., and Hekmat, S. (2015). Sensory evaluation of non-dairy probiotic beverages. Journal of Food Research, 4: 186.

Hossain, A., Begum, P., Zannat, M. S., Rahman, M. H., Ahsan, M., and Islam, S. N. (2016). Nutrient composition of strawberry genotypes cultivated in a horticulture farm. Food Chemistry, 199: 648-652. 
Huang, D., Ou, B., and Prior, R. L. (2005). The chemistry behind antioxidant capacity assays. Journal of Agricultural and Food Chemistry, 53: 18411856.

Jayamanne, V. S., and Adams, M. R. (2006). Determination of survival, identity and stress resistance of probiotic bifidobacteria in bio-yoghurts. Letters in Applied Microbiology, 42: 189-194.

Kavas, N., and Kavas, G. (2016). Functional Probiotic Yoghurt Production with Pomegranate (Punica granatum L.) Juice Concentrate Fortification. Journal of Scientific Research and Reports,10:1-10.

Kavas, N., and Kavas, G. (2016). Probiotic frozen yoghurt production using camel milk (Camelus dromedarius) with Improved functions by strawberry guava (Psidium littorale var. cattleianum) fortification. British Journal of Applied Science and Technology, 14: 1.

Kelebek, H., and Selli, S. (2011). Characterization of phenolic compounds in strawberry fruits by RP-HPLC-DAD and investigation of their antioxidant capacity. Journal of Liquid Chromatography and Related Technologies, 34: 2495-2504.

Keutgen, A., and Pawelzik, E. (2007). Modifications of taste-relevant compounds in strawberry fruit under $\mathrm{NaCl}$ salinity. Food chemistry, 105(4):1487-1494.

Lourens-Hattingh, A., and Viljoen, B. C. (2001). Growth and survival of a probiotic yeast in dairy products. Food Research International, 34: 791796.

Longton, M. (1991). The microstructure of yogurt. SIK yogurt, 580: 1-26.

Marxen, K., Vanselow, K., Lippemeier, S., Hintze, R., Ruser, A., and Hansen, U. P. (2007). Determination of DPPH radical oxidation caused by methanolic extracts of some microalgal species by linear regression analysis of spectrophotometric measurements. Sensors, 7: 2080-2095.

Mahmood, T., Anwar, F., Abbas, M., and Saari, N. (2012). Effect of maturity on phenolics (phenolic acids and flavonoids) profile of strawberry cultivars and mulberry species from Pakistan. International Journal of Molecular Sciences, 13:4591-4607.

Marshall, R. T. (1993). Standard methods for the examination of dairy products, $16^{\text {th }}$ ed. American Public Health Association, Washington, D.C.

Mansour, E., Ben, K., Ben, Y., Abid, M., Bachar, K., and Ferchichi, A. (2014). Fiber content and quality of pomegranate ( Punica granatum L.) cultivated in a coastal Oasis. International Journal of Current Microbiology and Applied Sciences, 3: 915-924.

Maurya, S., and Singh, D. (2010). Quantitative analysis of total phenolic content in Adhatoda vasica Nees extracts. International Journal of Pharm Tech Research, 2(4): 2403-2406.

Olajire, A. A., and Azeez, L. (2011). Total antioxidant activity, phenolic, flavonoid and ascorbic acid contents of Nigerian vegetables. African Journal of Food Science and Technology, 2: 22-29.

Ozgen, M., Durgaç, C., Serçe, S., and Kaya, C. (2008). Chemical and antioxidant properties of pomegranate cultivars grown in the Mediterranean region of Turkey. Food Chemistry, 111: 703-706.

Pereira, A. L. F., and Rodrigues, S. (2018). Turning Fruit Juice Into Probiotic Beverages. In Fruit juices (pp. 279-287). Academic Press. 
Poste L.M. (1991). Laboratory methods for sensory analysis of food, Canada. Department of Agriculture, P.,imprenta, Ottawa, 90 p. Edición, Ed. rev. Serie: Publication.

Quisumbing, E. (1978). Medicinal Plants of the Philippines Katha Publishing. Quezon City, Philippines, 640-642.

Radunic, M., M. Jukic Spika, S. Goreta Ban, J. Gadze, J.C. Díaz-Pérez, and D. MacLean. (2015). Physical and chemical properties of pomegranate fruit accessions from Croatia. Food Chemistry 177:53-60.

Ramaswamy, H. S. and Basak, S. (1992). Pectin and raspberryconcentrate effects on the rheology of stirred commercial yogurt. Journal of Food Science, 57: 357-360.

Saarela, M., Mogensen, G., Fonden, R., Matto, J. and Mattila-Sandholm, T. (2000). Probiotic bacteria :safety, functional and technological properties. Journal of Biotechnology, 84: 197-215.

Treftz, C., and Omaye, S. T. (2015). Nutrient analysis of soil and soilless strawberries and raspberries grown in a greenhouse. Food and Nutrition Sciences, 6: 805.

Van Hooijdonk, T., and Hettinga, K. (2015). Dairy in a sustainable diet: a question of balance. Nutr Rev, 73 (Suppl): 48-54.

Yıldız, Ö. (2008). Investigation of the pyhsical and chemical properties of milk containing antibiotics (Master's thesis, Izmir Institute of Technology).

Yousef, M., Nateghi, L., and Azadi, E. (2013). Effect of different concentration of fruit additives on some physicochemical properties of yoghurt during storage. Annals of Biological Research, 4: 244-249.

Zheng, X., Yu, Y., Xiao, G., Xu, Y., Wu, J., Tang, D., and Zhang, Y. (2014). Comparing product stability of probiotic beverages using litchi juice treated by high hydrostatic pressure and heat as substrates. Innovative Food Science and Emerging Technologies, 23: 61-67.

Zhang, Y., Du, R., Wang, L., and Zhang, H. (2010). The antioxidative effects of probiotic Lactobacillus casei Zhang on the hyperlipidemic rats. European Food Research and Technology, 231: 151-158.

Zoumpopoulou, G., Pot, B., Tsakalidou, E., and Papadimitriou, K. (2017). Dairy probiotics: Beyond the role of promoting gut and immune health. International Dairy Journal, 67: 46-60. 


\section{الملخص العربي}

\section{الخواص الكيميائيه الحيوية لمشروب الحليب المتخمر المدعوم بعصير الفراولة ويعض سلالات بكتيريا البروييوتك}

إيمان محمود محمد هارون', إيمان حسين السيد عياد' ,عزه احمد بكرى ',سعيد محسن درويش' قسم علوم الأغذية- كليه الزراعه سابا باشا - جامعه الإسكندريه- مصر قسم الأغذيه الخاصه - معهد بحوث وتكنولوجيا الأغذيه مركز البحوث الزراعيه الجيزة

انتشر في الآونة الأخيرة إستخدام منتجات الألبان كأغذيه وظيفيه نظرا لقيمتها الغذائيه المرتفعه وقبول المستهلك لها ABT5 (Lactobacillus ولذلك كان الهدف من الدراسه إنتاج مشروب لبنى متخمربواسطة الاستهان Streptococcus thermophilus. and Acidophilus LA-5, Bifidobacterium BB12)

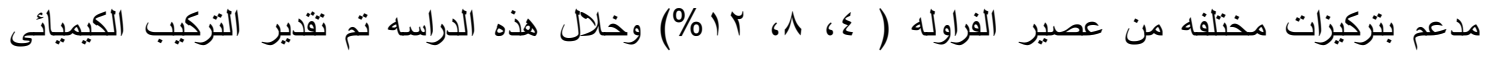
والفيزيائى وبعض المركبات الحيويه لعصير الفراوله وأوضحت النتائج للعصبر الطازج أن نسبه الرطوبه كانت

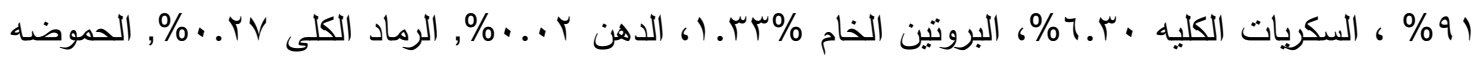

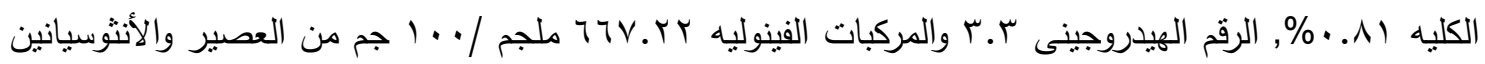

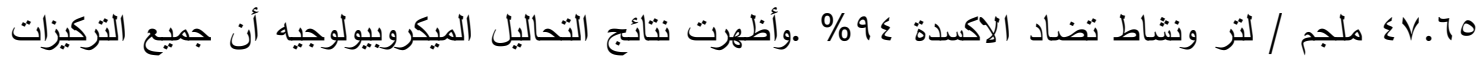
أدت الى زياده عدد البكتيريا الداعمه للحيويه وكان التركيز (ع , ^ \%) الأكثر قبولا لدى المحكمين حتى نهايه فتره التخزين ^ 1 أيام على درجه الحراره ؟ْ من الناحيه الحسيه ـ وأن المستوى الموصى به من البكتيريا ABT5

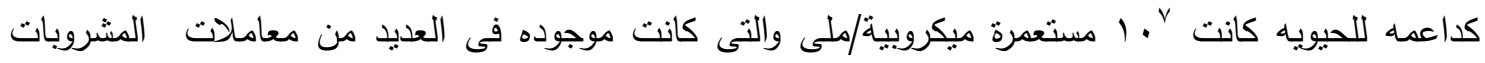

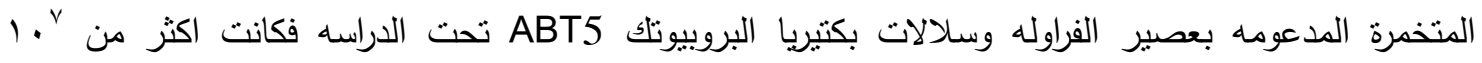

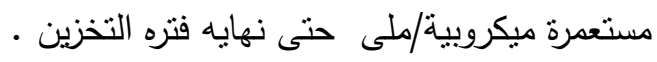


